\title{
ISLAM AND LOCAL TRADITION: A SOCIAL CAPITAL TO STRENGTHENING URBAN DEVELOPMENT IN KAMPUNG KOTA OF YOGYAKARTA.
}

\author{
UI ARDANINGGAR LUHTITIANTI \\ Universitas Islam Negeri Sunan Kalijaga Yogyakarta \\ Email: miyyazhafif@gmail.com \\ DOI: $h$ ttp://dx.doi.org/10.24952/fitrah.v5i2.1871
}

\begin{abstract}
ملحص
وجود القرية في المدينة بمحافظة جوغجاكرتا لا يخلو من تأثير القصر، ولذلك، أكثر الخصائص الموجودة من ججتمعها يتمسكو قويا على إعتقاد محلي على الشكل الرئيسي القيمة والقنون المشتقة

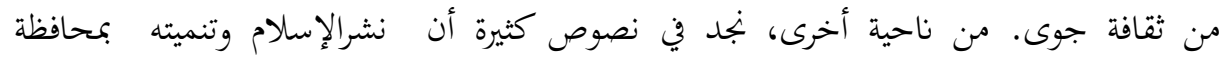
جوغجاكرتا لا يخلو من تأثير القصر أن طريق الدعوة التي يقوم بها الشيخ الحاج أحمد دحلان.

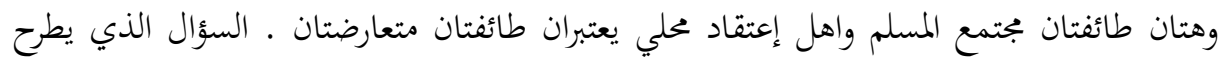
من هذه المشكلة هو: هل تستطيع هتان طائفتان المتعارضتان تتعاملان معا في بيئة واحدة ؟ كيف وهيف

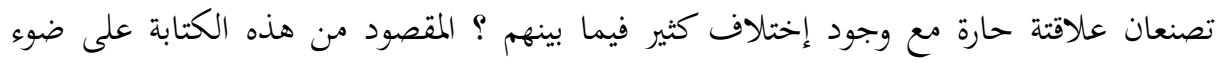
المعاملة الرموزية والتركبية الوظفية هو تصوير إجراء المعاملة المباشرة وإصدار نظام المجتمع المنظم وعلاقة حارة. التوسط والتسامح من عدة فعالية المجتمع التي تظهر من ذلك إجراء المعاملة المباشرة.

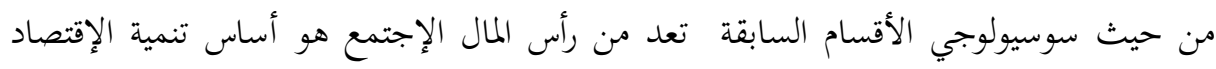

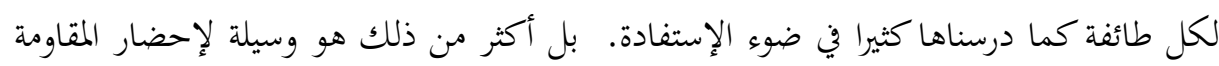
الإجتماعية . الإن مفاتح الكلمة: الإسلام، إعتقد محلي، رأس المال الإجتمع ، القرية في المدينة.
\end{abstract}

\section{Abstrak}

Keberadaan kampung kota di Yogyakarta tidak bisa dilepaskan dari pengaruh keraton, sehingga karakteristik masyarakatnya yang dominan adalah mereka masih memegang kuat kepercayaan lokal utamanya nilai dan norma yang bersumber dari budaya Jawa. Di sisi lain, banyak literatur yang menyebutkan bahwa pertumbuhan Islam di Yogyakarta juga tidak bisa dilepaskan dari pengaruh keraton melalui peran dakwah $\mathrm{KH}$ Ahmad Dahlan. Kedua kelompok ini, yakni Islam dan tradisi lokal seringkali dianggap sebagai dua kutub yang saling berlawanan. Pertanyaan yang sering muncul adalah dapatkah dua kelompok yang berbeda ini berelasi bersama dalam satu komunitas? Bagaimana mereka dapat membangun suatu hubungan yang harmonis 
dalam perbedaan identitas? Melalui perspektif interaksionisme simbolik dan struktural fungsional artikel ini bermaksud untuk mendeskripsikan bagaimana proses interaksi berlangsung dan memunculkan system sosial yang tertib dan harmonis. Keterbukaan, toleransi, saling mengakui, adalah beberapa tindakan sosial yang muncul dari proses interaksi tersebut. Komponen-komponen ini secara sosiologis dapat dikategorisasikan sebagai bagian dari modal sosial, suatu modal yang tidak hanya dapat menjadi basis pengembangan ekonomi komunitas seperti yang banyak dipelajari dalam perspektif pemberdayaan, namun lebih dari itu dapat menjadi sarana untuk mewujudkan ketahanan sosial.

Kata Kunci: Islam, tradisi lokal, modal sosial, kampung kota

\section{INTRODUCTION}

In the beginning of 2015, The Governor of Special Region of Yogyakarta announced "Yogyakarta Istimewa" as an official slogan. Historically, the meaning of "Istimewa" refers to previleges of Yogyakarta as a region, which in the political and governance aspect is under authority of the Sultanate of Yofyakarta. It implies that in the order of social life, the people of Yogyakarta entirely be based on Javanese cultural values. At least this is reflected in the tagline Memayu Hayuning Bawana taken from the cosmological philosophy of Javanese spirituality. Mulder ${ }^{1}$ has provided review the meaning of Memayu Hayuning Bawana as an ideal norm to get the real life. A doctrine of morality that wants people to maintain and preserve peace to achieve world safety, which means in the context of policy, the Government of Yogyakarta strives to adopt local philosophy as the basis for social development.

Values, norms, in the Sociological concept, are known as the forming elements of social capital. The concept of social capital was first introduced by Lyda Judson Hanifan², who commented that capital is not always related to something that is material and economic value, but also a sense of friendship, sympathy, compassion, and so on. This concept became more widely known after Pierre Bourdieu in the 1970s introduced cultural capital, economic capital, and social capital in the context of higher education in France. Bourdieu, in his

\footnotetext{
${ }^{1}$ Mulder, Niels. 2001. Mistisisme Jawa. Yogyakarta: LKIS, p. 59

${ }^{2}$ Hanifan, L. J. 1916. "The Rural School Community Center". Analys of The American Academy of Political and Social Science. p. 130
} 
writing The Forms of Capital $^{3}$, asserted that social capital is the overall relationship in the social network and institutions that based on mutual recognition and know each other, which would be the capital that could be owned collectively. Both Hanifan and Bourdieu shared this concept based on the educational aspects of their profession.

James Coleman, Robert Putnam and Francis Fukuyama also have provided their comments on forms of social capital based on their research findings. Coleman ${ }^{4}$ concluded that there were three (3) forms of social capital in a community group whom he studied, i.e; (1) expectatios that arise from mutual trust, (2) the continuity of information in the social network, and (3) norms that must be obeyed. As Putnam in his book Making Democracy Work: Civic Tradition in Modern Italy ${ }^{5}$ defines social capital as social features consisting of networks, norms, and beliefs, where among these three can bring mutual benefits between members of the group or community. The last Fukuyama, in his book Trust: The Social Virtues and The Creation of Prosperity ${ }^{6}$ state that to measure democracy and prosperity in a country can be seen from the trust among its citizens. Trust as element of social capital can be achieved if there is a set of norms of mutual assistance and cooperation, and familiarizing yourself wih local traditions cultures.

Putnam and Fukuyama have provided this concept to emphasize that the success of development achieved when there are elements of social capital among its citizens. It based on Putnam's research ${ }^{7}$, that social capital is a precondition to economic development and a prerequisite for the creation of good governance. Even, Putnam also concluded that social capital could be a brigde for ideologically different social group to join in community development.

Based on the results of the research above, it can further be construed that there are several aspects that can be referred to as social capital, i.e trust between

\footnotetext{
${ }^{3}$ Bourdieu, Pierre. 1983. "The Forms of Capital", dalam J. Richardson, ed. Handbook of Theory and Research for the Sociology of Education. Westpost, CT: Greenwood Press

${ }^{4}$ Coleman, James S. 1988. Social Capital in the Creation of Human Capital. American Journal of Sociology 94: S95-S120

${ }^{5}$ Putnam, Robert \& Robert Leonardi \& Rafaella Nanetti. 1993. Making Democracy Work: Civic Traditions in Modern Italy. Princeton, N.J: Princeton University Press, p. 36

${ }^{6}$ Fukuyama, Francis. 1995. Trust: The Social Virtues and the Creation of Prosperity. New York: The Free Press

${ }^{7}$ Putnam, Robert \& Robert Leonardi \& Rafaella Nanetti. 1993. Making Democracy Work: Civic Traditions in Modern Italy. Princeton, N.J: Princeton University Press
} 
members of the community, habits in the traditional culture, mutual relationship, norms, and finally inclusive. Next, Putnam explained that these six (6) aspects if fulfilled in a society will encourage the realization of good governance, community resilience, social harmony, and the achievement ofeconomic prosperity. Many community groups and civilizations have high social resilience because they have a strong social capital.

Yogyakarta city, as an urban area within the Yogyakarta Province, has a distinctive character in the order of their social life. Unlike other big cities which mostly have invididual characteristics, unreligiousity, and rasionality, Yogyakarta's City has Javanese cultural values that are reflected in every symbol of governance and in their social life, all of which can maintain mutual attitudes, trust, harmony and inclusivity, which when referring to the concepts of Putnam, Coleman, and Fukuyama, these aspects are part of social capital.

Ahmad Najib Burhani ${ }^{8}$ in his Muhammadiyah Jawa's book, explained that keraton is a symbol of the cultural center, values, norms, and even religion, for the Javanese people. It indicates that the citizens of Yogyakarta not only have cultural aspects as a source of strength in social capital, but the role of religion (Islam-red) also has a strong influence on the religious life of Yogyakarta's citizens. Woodward ${ }^{9}$ even concluded that by looking at keraton, we would know how much influence Islam had on Java. It is because, according to him, Islam is the theocratic foundation for palace in Java. Islam is so persasive among the keraton that it becomes a reference standard of etiquette and ethics for Javanese people. Thus, it can be said here that there has been a relationship between Islam and Javanese society before, which we can then ask a question how the relationship model in the context of Javanese today of Yogyakarta society?

Then it becomes interesting to see why and how social capital can still survive amidst the diversity of values in Yohyakarta society. Does this relate to the relationship between Islamic values carried by religious organizations and local traditions and beliefs? How does the interaction process produce a harmonious relationship between the two entities? Based on this background, using the

${ }^{8}$ Burhani, Ahmad Najib. 2010. Muhammadiyah Jawa. Jakarta Selatan: Al Wasat Publising House

9 Mark R. Woodward. 1996. Toward a New Paradigm: Recent Developments in Indonesian Islamic Thought. Arizona: Arizona State University, on Burhani, Ahmad Najib. 2010. Muhammadiyah Jawa. Jakarta Selatan: Al Wasat Publising House 
perspective of symbolic interactionism, this article intends to describe how the interaction of the two actors in several kampung in Yogyakarta, in this case, the author took in three kampung, i.e; Ndalem, Panembahan, and Gondolayu. Furthermore, using the structural-functional perspective, this article also aims to explore how the religious relations and cultural values of Java can strengthen the social capital of urban communities and can be a basis of ueban development policy programs.

\section{METHODS}

This article used qualitative research and literatur study, within informal interviews by nine (9) informants, i.e: the local figures and several citizens in Ndalem, Panembahan, and Gondolayu. Ndalem is the first Njero Benteng Kampung since the establishment of Mataram Islam. Panembahan, as a representation of the current Njero Benteng Kampung, Gondolayu which has relatively many migrants there. Data were analyzed using interactive analysis techniques, where data was reduced according to the needs of the research topic, then presented in the form of descriptive narratives and analyzed using symbolic interactionism theory and structural-functional.

\section{DISCUSSION}

\section{A. Get to Khow Kampung Kota of Yogyakarta as a Historical Fact}

Yogyakarta, when we hear the name of this city, our imagination will lead to the keraton, the beauty of nature, diverse of tourist attractions, unique culinary, batik, or even disaster-prone areas. Not all of the peoples know how the potensials of Yogyakarta's City that manifest in the tourism object a part form the township. John Sullivan ${ }^{10}$ in his dissertation, said that in Indonesia, the term of kampung is often applied to refer to urban areas, although in some other places such as in Malaysia kampung means to refer to rural areas. In describing this kampung in Indonesia, Sullivan described kampung kota as a dense area that could not be reached by cars or motorcycle, he said that this tye of village was the original type of settlement in Indonesia. Meanwhile, to describe the dense of kampung area which is on the outskirts of the city and synonymous with an

${ }^{10}$ Sullivan, John. 1986. Kampung and State: The Role of Government in the Development of Urban Community in Yogyakarta. Cornell University Press; Southeast Asia Program Publication at Cornell University. No. 14 April 1986,. Pp. 63-88 
economic and ecological vulnerability that has not been balanced, Sullivan called it an illlegal kampung.

According to this definition, kampung scattered in Yogyakarta are basically almost similar as descrideb by Sullivan. Where there are illegal kampung and native kampung, the native kampung are usually occupied by indigenous citizens of Yogyakarta, and illegal kampung are usually filled with many migrants. These migrants occupy lands belonging to keraton that are along the Code River and Gadjah Wong river. Whie the original kampung is located around the palace. In this section, only discuss kampung kota that is part of the original kampung of Yogyakarta.

Historically, kampung kota in Yogyakarta is an urban area that was once a stub of the princes and the servants of keraton (who called abdi dalem in Javanese language) who serve daily activity in keraton. Gunawan and Harnoko ${ }^{11}$ explained the division of kampung in Yogyakarta in 2 (two) regions, the first being Kampung Njero Benteng which was an extraordinary settlement fr aristocratic class of royal relatives and abdi dalem. Abdi Dalem occupy kampung outside keraton and daily duty takes care keraton. So it is not surprising if the naming of Njeron Benteng Kampung is taken following with the division of roles among abdi dalem. For example, Kampung Siliran is a residence of abdi dalem who take care of palace lights. Kampung Gamelan is the residence of abdi dalem who takes care of the palace horses. Kampung Pasindenan for palace entrepreneurs, Kampung Langenastran and Langenarjan for palace warriors, Kampung Patehan for those who take care of drinks, Kampung Nagan for Gamelan hitters, and Kampung Suronatan which is the residence of ulama.

The second villages area is Njaban Benteng. These kampung are settlements of abdi dalem who do not take care of keraton households and are also areas of professional groups outside abdi dalem, such as in the fields of government, military, carpentry, craftsmen, and nobility ${ }^{12}$. The villages include Kampung Pejaksan (the village of presecutors), Kampung Gandekan (palace courier), Dagen Village (carpenter), Jlagran (crafters, stylists), Kampung Gowangan (construction expersts), Kampung Menduran (place of carpenter live

11 Gunawan, Ryadi \& Darto Harnoko. 1993. Sejarah Sosial Daerah Istimewa Yogyakarta: Mobilitas Sosial DI Yogyakarta Periode Awal Abad Duapuluhan. Jakarta: Cv. Manggala Bhakti, p. 19

${ }^{12}$ Gunawan, Ryadi \& Darto Harnoko. 1993. Sejarah Sosial Daerah, p. 19-20 
Madurese), Wirobrajan, Patangpuluhan, Daengan, Jogokaryan, Prawirotaman, Ketanggungan, Mantrijeron, Nyutran, Sukokarsan and Bugisan, which are the settlements of palace stroops since eraton was built by Sultan Hamengku Buwono II. And many more other kampung which usually consist mostly of the same professional group, such as Kauman which is the ulama keraton, Mergangsan, Gedong Tengen, and so on.

Now, urban villages have experienced development in terms of population, socio-cultural, and economic differentiation. Historically, the cultural contact between Javanese and Europe and the religions that developed at that time also contributed to the social mobility of citizens ${ }^{13}$. The relationship between priyayi and commoners that have been built since the formation of social stratabased village settlements above has experienced a shift in line with the development of educational institutions in Yogyakarta ${ }^{14}$, which gives the consequences of the arrival of new cultures from students who come from various regions and countries. All these aspects are very influential in changing relations between social classes of Javanese people, social mobility, and of course, changes in socio-cultural values that are adhered to by citizens. The villages are slowly undergoing territorial adherence, which then leads to the condition of the village transition with rural to urban.

If we try to trace every corner of the kampung of the city of Yogyakarta, we will see the different characteristics of each kampung. Kampung are no longer "functioning" as they were originally named. In the Njeron Benteng area, we will see various batik and tourism industries, while in Njobo Benteng we will see the growth of new villages which John Sullivan calls illegal kampung. The villages grew along the Code River, Khudori in his book Menuju Kampung Pemerdekaan ${ }^{15}$ explained that the people who occupied the Code area initially occupied the grave ground around Gondolayu and Bumen. This land is the Sultan Ground area. On average, they are migrants seeking an economic livelihood in Yogyakarta. Its strategic location adjacent to the Beringharjo and Kranggan markets makes this area more fertile with an increasing number of migrants. Not

\footnotetext{
${ }^{13}$ Gunawan, Ryadi \& Darto Harnoko. 1993. Sejarah Sosial Daerah...., p 45-46

${ }^{14}$ Gunawan, Ryadi \& Darto Harnoko. 1993. Sejarah Sosial Daerah...., p 71

15 Khudori, Darwis. 2002. Menuju Kampung Pemerdekaan: Membangun Masyarakat Sipil dari Akar-Akarnya Belajar dari Romo Mangun di Pinggir Kali Code. Yogyakarta: Yayasan
} Pondok Rakyat 
only in Code, but other illegal villages appeared along the banks of the Gadjah Wong river. In general, they were also migrants. They were occupying the area up to establish a permanent building as a residence.

Some other kampung that have experienced this transition are Kampung Prawirotaman and Kampung Sayyidan. Prawirotaman is no longer occupied by palace warriors (prajurit-red). But now it has developed into an urban village with residents who mostly earn their living as souvenir sellers and souvenirs typical of Yogyakarta. Then, come Sayyidan, which had been a village of scholars and Arabs, has turned into a musician town of Yogyayakarta. Some other villages, such as Mataraman, have been transformed into tourist villages with various unique characteristics of the region.

This change certainly got an influence on socio-cultural values, which from the beginning became a bind between citizens. This change is certainly not always of negative value, as the cited by Tonnies and Durkheim that the change of a community-patterned area into a patembayan is characterized by symptoms of fading social ties (solidarity) in society. In the Yogyakarta context, historical factors in the form of cultural contact and religious relations with the local culture mentioned earlier can give rise to new values that have become evolutionary bind to strengthen social capital in society.

\section{B. Islam and The Shifting in Traditional Local Culture}

1. Trust, Togetherness and Norms: An Overview of the Strength of Social Capital in the Kampung Kota of Yogyakarta

As stated in the introduction, the elements in social capital can be categorized as among others, trust between members of community, habits in traditional culture, mutual assistance and cooperation, the norms existence, people relationship, and finally is inclusive. In some kampung in Yogyakarta, these elements are still well maintained.

Elements such as trust, amins to maintain norms through etiquette are still very strong among the elderly. Togetherness is still maintained through recitation forums, associations, community deaths, ser kiler, and so on. While in the aspect of traditional cultural habits, Kampung Ndalem, for example, the people there do not hold many rituals or customs related to traditional Javanese culture, including Panembahan and Gondolayu. 
This condition very interesting to observe because, geographically, Ndalem is part of the Kotagede Subdistrict area. As history reveals, Kotagede was once the center of the Islamic Mataram empire in Ki Ageng Pemanahan before finally moving to the current palace. With these factors, it is not surprising that Ndalem has many varieties of community activities that reflect the appreciation of Javanese cultural values.

When exploring the existence of local traditions through informal discussions with some citizens and community leaders, some activities such as tahlilan, kenduri, nyadran, pilgrimage to the tomb have been largely abandoned by some citizens. As a tradition of inheritance from Javanese cultural values, then supported by the historical side of Ndalem as the petilasan village of Raja Mataram Islam, these traditions should be maintained. But in fact, it is the tourist from outside Ndalem who preserve it more.

Come together with the values of $d a^{\prime} w a h$ Islam, in this case Muhammadiyah, it is consideres by some people of Ndalem as an evolutionary factor that has eroded these various traditions. This gives a new color to the community regarding the way of Islam in accordance with what they believe. Gradually, kenduri (the feast-red), tahlilan (pray together-red), nyadran (serve some food for 'God'-red), began to be abondaned by some citizens. What they interpreted as an effort to remember the deaths of citizens with festivity and tahlilan was replaced with tadarus in the homes of deceased relatives. On the occasions of an open interview, the reduced interest of some citizens in the efoort to preserve local traditions led to some degree of conflict, however the nature of the conflict was still on the surface, limited to differences in the way of viewing Islamic values. In other words, it does not have a significant influence on the harmonization of society.

This strengthening of religious enthusiasm did not only occur in Ndalem, but also in Panembahan and Gondolayu. In Panembahan, its geographical location which is part of Njeron Benteng as is the case with Ndalem whose early Islamic Mataram was also a region of Njeron Benteng, enabled the internalization and dissemination of Kejawen values in the community to be well maintained. However, its contact with Islamic values has made citizens gradually abandon the tradition of 40 days, 100 days, and so on. And other traditions such as nyadran and apeman are only a small part of the citizens who preserve it. 
In Gondolayu, the local traditions mentioned above have been abandoned by many residents. Besides being a factor of demographic change due to the large number of migrants who come to the place and bring new values, it is also due to the increased awareness of religious understanding among residents. Regular study forums held by the mosque increase citizen participation to increase awareness of the understanding of religious diversity in the community. This change of view in addressing local traditions does not then automatically make other aspects of social capital fade. In these three villages, togetherness, trust, getting to know each other, even tolerance among residents is still very strong, with different forms of activity and more religiously nuanced.

Sunyoto Usman ${ }^{16}$ said that the phenomenon of people's appreciation of religious values in developing countries emerged since the 1970s. There are 3 (three) aspects that characterize this phenomenon. First, the desire of religious communities to carry out religious law in a more kaffah, round, and touch the entire niche of life. Second, placing fellow believers as a community unity that is inseparable from blood, region, or ideology. Third, to mobilize the potential of fellow believers into various forms of a religious organization, so that it can be solved more effectively. In fact, it cannot be denied that the people of Yogyakarta have gone through a process of Islamic internalization carried out by the religious elite. But, the question is whether then this is something negative?

\section{Analyzing the Relation of Islamic Value and Local Traditions With Interactionism Symbolic and Structural-Functional Perspective}

To answer that question, there are aome point that not only changes in social values that have long been rooted in characterizing something that is destructive (damaging the social order which has long been established). First, the existence of Muhammadiyah, for example, in bringing Islamic value in the urban villages, which on average are still considered to have not performed religious deeds according to to their beliefs, in fact, did not bring up something destructive. As a general belief, changes in certain values and norms in a society can be considered to threaten the stability of that society. Conflicts may appear on the surface, but the dynamics that occur in the community can just neutralize and even reduce the conflict. Third, the shift of local traditions to study forums

${ }^{16}$ Usman, Sunyoto, 2004. Pembangunan dan Pemberdayaan Masyarakat. Yogyakarta: Pustaka Pelajar, p. 32 
does not then eliminate the elements of social capital of citizens, togetherness and preservation of norms are still well preserved. From these three things, we can assume the relation of the character of the people in several villages in Yogyakarta that are open to new values. From this, the inclusive and tolerant attitudes of the two groups can form a social capital that can ultimately be used to build community endurance.

Theoretically, the three things above can be explained through 2 (two) Sociological perspectives, both at the micro and macro level. The assumption is that the interaction of these two values at the micro-level can be the basis of policy at the macro level, especially in the context of urban development policy. In this case, we can use the perspective of interactionism symbolic and structuralfunctional. The perspective of interactionism symbolic is used to explain how the interaction between the two actors (citizens and members of religious organizations) raises compromises at the level of community activities. While the functional-structural perspective is used to explain how the dynamics in the process of changing values can strengthen various functions in society so that it can ultimately form social harmony.

Some figures known in the perspective of symbolic interactionism include Blumer and Mead. Blumer ${ }^{17}$ explained that there are at least 3 premises that we need to pay attention to when we use this perspective. First, humans act on something according to the meaning that thing to them. Second, the meaning of something arises from one person's interaction with another. Third, the meaning is interpreted when someone is related to the things. From these three aspects, we can conclude that symbols, interactions, and interpretations are the basis for someone to do a certain action.

In the context of the interaction of Muhammadiyah's members with local citizens in the three urban villages, there are three keywords to understand how the relationships between them are well developed. These three things are, the meaning of tradition / ritual and shari'a as a symbol between the two actors in a reciprocal manner, the interaction and the meaning of each actor with the values that shape their respective lives, and then the meaning becomes the basis for each actor to address both tradition and the Shari'a. Before describing how this

\footnotetext{
${ }^{17}$ Ritzer, George \& Douglas J. Goodman. 2004. Teori Sosiologi Modern. Jakarta:Prenada Media
} 
symbolic interactionism works in the relationship between Muhammadiyah and Kejawen, it is necessary first to describe the history and values of Javanese culture, which are the beliefs of the people which form the basis of their interpretation of 'others'.

Koentjaraningrat ${ }^{18}$ explained the typical Javanese people in the north (pantura) and the south, where Islam in the south is more syncretic, like in Yogyakarta, Klaten, and Surakarta. According to Partokusumo, this syncretic style was born as a result of the intersection of Javanese culture with Islamic values that brought from Persia and India. There is some differences opinion regarding the history of the source of Islam's entry into Java, who argue from the trade routes of the Arabs, and some other experts view that Islam that came to Java was from Persia and India. There are similarities between Persian and Indian Islam with Javanese traditions and way of life. Because of this interaction process, what Koentjaraningrat appears to be is Kejawen Islam. A belief that emerged as a point of compromise between Islamic values and local traditions.

So, many relations between Muslims and Kejawen communities were conflicting. Ahmad Najib Burhani explained that Javanese people have certain norms that are believed to originate from Hindhu-Buddhist influence. Their concept of 'how' (procedure) does something derived from Javanese philosophical views. For example, how to educate children with karma and language, find a match for their children through the knowledge of 'petungan', marry their children through certain procedures, how to treat newborns to a certain age with certain procedures. All of these procedures become social traditions that are believed, practiced, and passed on through continuous socialization in the family and community.

Suyanto ${ }^{19}$ explained that the Javanese had the characteristics of believing in something supernatural. Such as the concept of God they defined as Sangkan Paraning Dumadi, believing in everything that was immaterial and supernatural (mystical), compassion, believing in total destiny and submission, convergent and universal, tend to symbolism, give priority to mutual cooperation, harmony and peace, lack of competitive spirit and do not prioritize the material.

${ }^{18}$ Koentjaraningrat, 1995. Manusia dan Kebudayaan di Indonesia. Jakarta: Jambatan., p.

${ }^{19}$ Suyanto. 1990. Pandangan Hidup Jawa. Semarang: Dahana Prize., p. 144
} 
This view of life is the basis of their daily interactions with those around him. Their belief in Sangkan Paraning Dumadi, the tendency to display many symbols, and their belief in everything that is mystical, for example, underlies them to perform certain rituals on certain days. Examples such as mitoni, ngalap berkah, kenduri, nyadran all of which were born from their internalization process of the Javanese philosophy. Including those in the introduction, I explains about the tagline Memayu Hayuning Bawana, then the slogan of Segoro Amarto which implies harmony, togetherness, mutual cooperation, that they mean it and practice it in their lives.

Meanwhile, on the other hand, the Islamic values brought by Muhammadiyah have historically been inseparable from the influence of keraton and Javanese culture. These two aspects, according to Ahmad Najib Burhani, greatly influenced Muhammadiyah's religious views, specifically related to its relationship with Javanese culture. The intersection of $\mathrm{KH}$ Ahmad Dahlan as Ketib Amen, who is in charge of taking care of the religious ceremonies of keraton, such as Grebeg Maulud and Grebeg Besar, by Ahmad Najib Burhani is referred to as a means of opening the way for $\mathrm{KH}$ Ahmad Dahlan to communicate with the Sultan. It can be concluded here that based on historical aspects, Muhammadiyah, through its main character, actually had a lot of contact with Javanese culture from the beginning and did not cause significant opposition to ceremonies such as Grebeg.

Thus, if we then analyze it by using the theory of symbolic interactionism, the first aspect of the values and symbols that hold onto each actor can be fulfilled. Why did good relations emerge between Ndalem, Panembahan, and Gondolayu residents and Muhammadiyah's member who also lived there? Because they both have the same historical roots of interaction, and the values and philosophies they internalize in their lives are similar. For example, love as a foundation in dealing with fellow human beings that characterizes the Javanese, in harmony with the values of love and compassion in Islam that is called ukhuwah. So when the two actors interact, a new meaning occurs to the person who is opposed to them, then the meaning they represent again in the form of social action. Concretely is the action to be more tolerant, mutual recognition, and tend to allow for others. 
The attitude of some citizens to be more opened towards Islamic values is the result of their interactions with the Javanese values that they have been upholding (religious, love, tepo seliro, and so on). In Herbert Mead's symbolic interactionism, this process emphasizes the aspect of self, where a person makes himself a social object by internalizing and reflecting on these values. The process then continued with manipulation ${ }^{20}$, which Mead also called human ability to distinguish it from animals. A person will think, research, and maybe discuss with his mind to determine his actions towards the attitudes of others. For example, will it benefit him or not? Do these actions contradict the values that they have been upholding? It might even be speculated what would happen if he did certain actions, for example, 'defense' or tolerate? As seen in the results of interviews with Gondolayu residents who stated that some residents began to consider whether their actions were in accordance with religious values or not.

At this stage, there is a thought process that Mead calls Mind, not in the sense that a person has a conversation with himself and is not found in the individual, but it is a social phenomenon. Concretely, that the Mind to ask whether the tradition they have been doing is right or not according to religion is a social phenomenon, no longer merely the mind of an individual. It means that the thought process of an individual can bring about social responses. The thought that Kejawen rituals had no guidance in Islamic value rise to the reaction of the community to follow the guidance of Muhammadiyah's religious beliefs. Up to this stage, emerged as self where when citizens are confronted with the new values shown by Muhammadiyah members, they unconsciously reflect that to themselves.

Likewise, citizens who are affiliated with Muhammadiyah, they act following the values that they believe so far. Then when they encounter the people of Kejawen, they reflect and adjust to tradition. It was revealed in interviews with local leaders that many Muhammadiyah members began to try to tolerate some traditions that were not in accordance with the principles of the religious value that they professed ${ }^{21}$.

${ }^{20}$ Ritzer, George \& Douglas J. Goodman. 2004. Teori Sosiologi Modern. Jakarta:Prenada Media, p. 275

${ }^{21}$ Interview with local leader, Sept 2019 
Symbols, minds, self, then complemented by Blumer's opinion about the values that have been internalized within a person and society, can bring about new social actions that are more meaningful for both parties. Among them are openness, tolerance, self-acceptance of the beliefs of others, participating in new traditions and values but not later dissolving in them. In Ndalem Kotagede, for example, there must be a point of an agreement while still allowing one another. In reality, however, this can be seen as a subtle da'wah strategy through symbols that are represented in tolerating, reciting activities, and so on.

It could be the answer why not many Ndalem people perform rituals in Hastarengga's tomb or other places, and more foreign tourists preserve it. In Panembahan, for example, some traditions such as tahlilan are still carried out by residents. Including nyadran, festivity, apeman, and 100-day commemoration, 1000-days are always well maintained ${ }^{22}$.

In the end, the new meaning of each other's self-belief, and how they interpret different cultural and religious values, lead people to be inclusive and tolerant of one another. It can be categorized as social capital to create community harmony, what Putnam described as the power to bring public participation in the development process and as a prerequisite for achieving a democratic society. A society in the context of religious social life no longer manifests in the relation of domination and hegemony of discourse which is superior to whom, but a harmonious relationship by filling in and understanding of other.

\section{Religion and Cultural Values: Social Capital as A Basis for Strengthening Social Risilience}

In the perspective of symbolic interactionism, Herbert Mead explained that when a human mind can bring about collective action in a community, then this can also lead to the formation of social institutions ${ }^{23}$. What happens at the individual level can be used by actors to internalize attitudes towards a new value at the community level. Furthermore, it can be used as a basis for certain policies to guide behavior in society.

\footnotetext{
${ }^{22}$ Interview, Sept 2019

${ }^{23}$ Ritzer, George \& Douglas J. Goodman. 2004. Teori Sosiologi, p. 287
} 
It means that the meaning of the two actors of their values and their interpretation of the 'other' which then manifests in actions/attitudes of openness and mutual respect for differences, can be used as the social policy for citizens and government. If referring to the opinions of several theorists regarding aspects of social capital, the two attitudes above can be categorized as a form of social capital. Social capital, as Putnam argues, is a potential capital for economic development, democratic political culture, and good governance (bureaucracy). The ability of people to maintain Javanese cultural values such as unggah-ungguh, local traditions, and even their ability to adapt to new values that come from religion is a potential cultural capital for the development of tourism social and economic policies.

Parsons ${ }^{24}$ regarding society is a social system that has interrelated parts of one another. Each of these parts has functions that support each other, influence, and are interdependent. According to Parsons, social order has been created in the social structure, which means that social systems can reverse or prevent the tendency of deviations in society, for example in the context of Islamic relations and traditions, when all systems run well in accordance with their functions, then this will minimize conflict, prevent violence between groups, and the most important is the emergence of social harmony.

Picture 1.

Drawing Social System to Support Urban Development with Religius and Lokal Traditions Aspects (According Structural-Functional Perspective)


${ }^{24}$ Ritzer, George \& Douglas J. Goodman. 2004. Teori Sosiologi., p. 126-127 


\section{Economic System}

The Economic development of tourism based on local values of urban villages (kampung religi, kampung, kampung sayur, etc.)

$\rightarrow$ there is a process of togetherness, local culture, trust, openness, mutual respect.

\section{Government System}

Urban development policy based on the social capital of urban villages

There is a reciprocal relationship, the interplay between systems, and one system with another system gives birth to a cyclic process that does not stop producing value, promoting value, bringing forth policies, including supporting the economic development of society as a necessity to survive. For example, the internalization of different values of different community actors is carried out through cultural preservation and religious activities. Then, when the symbolic interaction process they work in the community can give birth to an attitude of openness and tolerance without great conflict. This openness and tolerance among citizens can be a social capital that can be produced by the city government through policy intervention. For example, urban-based urban development policy. This scheme can also answer why the people of the city of Yogyakarta, even though it has been divided by the government within the scope of the RT and RW, still maintains the term village with all its characteristics, including in the development of the tourism economy.

Efforts to maintain the tradition of the village are seen in the efforts of the Yogyakarta City Government to develop various economic potentials for villagebased tourism. For example, a vegetable village, a tourist village, a religious village, and so on. If we use Putnam and Fukuyama's perspective, to realize all of this well then society needs the strength of social capital, such as trust, getting to know and acknowledge each other, openness, the ability to be able to appreciate differences and control oneself over those differences, especially as we discussed earlier that Yoyakarta community is very plural. Adam Smith ${ }^{25}$ even stressed that the economic development of a society without cultural values is impossible, and CV. Qalam

${ }^{25}$ Muller, 1992. Adam Smith and His Time and Ours, Terjemahan Ruslani. Yogyakarta: 
will only further strengthen the system of capitalism. In the end, this can be a policy recommendation for the Yogyakarta city government, to continue to maintain, develop the urban village based on the social capital they have.

\section{CONCLUSION}

Inclusiveness and tolerance are two words that the author can conclude with regard to the character of Islamic interaction and local traditions. Both of these groups can be components of social capital in urban village development, especially for urban areas that are heterogeneous in terms of religion and culture. As a city with strong Javanese cultural values, as well as a place of massive Islamic development, it is interesting to see that it turns out that Islam and Kejawen can be well correlated. The perspective of symbolic interaksionism and structural functional explains us how the interaction of Islam with local traditions, as the two majority entities in Yogakarta, can grow together in harmonious nuances and bring up these components of social capital.

Reflecting on the characteristics of Islamic relations and Javanese culture, we learn that the desire to control or dominate a particular society can be mitigated by good relations through this inclusive and tolerant attitude. As two large entities in a pluralistic society that have interacted for centuries, we should reflect at whatever level of community we are in, that harmony is the biggest dream in social life. That conflict is a social fact, but through the attitudes above we can learn to become members of society who understanding other entities completely. This is social capital that can teach us to grow into a big nation. Thus, tolerance and inclusiveness no longer only at the discourse at the academic level, but both must manifest in the pattern of our behavior as humans in everyday life. 


\section{REFERENCES}

Adaby Darban, Ahmad, 2000. Sejarah Kauman: Menguak Identitas Kampung Muhammadiyah. Yogyakarta: Terawang

Asrofie, M. Yusron, 1983. Kyai Haji Ahmad Dahlan, Pemikiran dan Kepemimpinannya. Yogyakarta: Yogyakarta Offset

Bourdieu, Pierre. 1983. "The Forms of Capital", dalam J. Richardson, ed. Handbook of Theory and Research for the Sociology of Education. Westpost, CT: Greenwood Press

Burhani, Ahmad Najib. 2010. Muhammadiyah Jawa. Jakarta Selatan: Al Wasat Publising House

Coleman, James S. 1988. Social Capital in the Creation of Human Capital. American Journal of Sociology 94: S95-S120

Fukuyama, Francis. 1995. Trust: The Social Virtues and the Creation of Prosperity. New York: The Free Press

Gunawan, Ryadi \& Darto Harnoko. 1993. Sejarah Sosial Daerah Istimewa Yogyakarta: Mobilitas Sosial DI Yogyakarta Periode Awal Abad Duapuluhan. Jakarta: Cv. Manggala Bhakti, hal. 19

Hanifan, L. J. 1916. "The Rural School Community Center". Analys of The American Academy of Political and Social Science.

Khudori, Darwis. 2002. Menuju Kampung Pemerdekaan: Membangun Masyarakat Sipil dari Akar-Akarnya Belajar dari Romo Mangun di Pinggir Kali Code. Yogyakarta: Yayasan Pondok Rakyat

Mark R. Woodward. 1996. Toward a New Paradigm: Recent Developments in Indonesian Islamic Thought. Arizona: Arizona State University

Muller, 1992. Adam Smith and His Time and Ours, Terjemahan Ruslani. Yogyakarta: CV. Qalam

Mulder, Niels. 2001. Mistisisme Jawa. Yogyakarta: LKIS

Nakamura, Mitsao. 1993. The Crescent Arises over the Banyan Tree. Yogyakarta: Gadjah Mada University Press

Partokusumo, Karkono Kamajaya. 1995. Kebudayaan Jawa Perpaduannya dengan Islam. Yogyakarta: Aditiya Media

Putnam, Robert \& Robert Leonardi \& Rafaella Nanetti. 1993. Making Democracy Work: Civic Traditions in Modern Italy. Princeton, N.J: Princeton University Press 
FITRAH Jurnal Kajian Ilmu-ilmu Keislaman

Vol. 05 No. 2 Desember 2019

Ricklefs, M.C. “Culture, Ethnicity, and Religion as Process: Inter-Culturality as the Key to the Future" dalam Kultur: The Indonesian Journal for Muslim Cultures, Vol. I, No. I, 2000.

Ritzer, George \& Douglas J. Goodman. 2004. Teori Sosiologi Modern. Jakarta: Prenada Media,

Suyanto. 1990. Pandangan Hidup Jawa. Semarang: Dahana Prize

Sullivan, John. 1986. Kampung and State: The Role of Government in the Development of Urban Community in Yogyakarta. Cornell University Press; Southeast Asia Program Publication at Cornell University. No. 14 April 1986

Usman, Sunyoto, 2004. Pembangunan dan Pemberdayaan Masyarakat. Yogyakarta: Pustaka Pelajar

Koentjaraningrat, 1995. Manusia dan Kebudayaan di Indonesia. Jakarta: Jambatan 